\title{
Merancang Panel Kontrol Untuk Pompa Air dan Motor Pengerak Solar cell
}

\author{
Herisajani, Nasrul \\ Yandrika Putra
}

\begin{abstract}
ABSTRAK
At this present time increasing electrical energy requirements, and therefore found the latest energy is solar energy. Solar energy can be harnessed as a potential alternative energy source because the energy is very large as well as environmentally friendly. Tool that can be used to convert sunlight directly into electricity is called photovoltaic. On the control panel to control the water pump on the motor control circuit design life turns automatically and manually. To control the timing of the displacement of the pump used to pump two timers. On the control panel of diesel propulsion sell used four times the displacement step. Switching time between steps in the set by a timer. The control panel uses the same circuit with the motor circuit alternating rounds.
\end{abstract}

Key words: solar module, water pump control panels, control panels and solar cell propulsion battery resilience.

\section{PENDAHULUAN}

\subsection{LATAR BELAKANG}

Air adalah salah satu dasar kebutuhan manusia baik untuk keperluan hidup sehari-hari dari kebutuhan untuk minum dan masak, keperluan sanitasi, dan untuk kebutuhan yang menunjang agrobisnis dan proses produksi. Ketersediaan air yang memenuhi syarat untuk memenuhi kebutuhan masyarakat tersebut di atas, sering menjadi masalah terutama pada daerah yang sumber air permukaannya sangat terbatas atau air bawah tanahnya sangat dalam. Meskipun teknologi peralatan pompa untuk memperoleh air telah tersedia dan mudah diperoleh, tetapi pada daerahdaerah tertentu, ketersedian tenaga penggerak pompa sering menjadi kendala, misalnya karena ketiadaan jaringan listrik PLN atau pada daerah yang sudah mampu menyediakan generator set (genset) tetapi sulit mendapatkan suplai BBM. Saat ini teknologi listrik tenaga surya (solar energy system) menjadi popular yang diyakini dapat mengatasi hambatan tersebut di wilayah tropis, cahaya matahari dapat diperoleh secara cuma-cuma sepanjang tahun di mana saja, di tempat terpencil sekalipun. Jadi pemanfaatan teknologi tenaga listrik tenaga surya untuk menggerakan pompa air sangatlah ideal. Dengan penjelasan yang telah dikemukakan maka penulis menetapkan judul tugas akhir Pemanfaatan Energi Surya Untuk Penggerak Pompa Air Sebagai Pemberdayaan Ekonomi Masyarakat.

Secara keseluruhan system ini dirancang untuk penyediaan air dengan sumber energy yang terbarukan. Biaya perawatan murah dan berumur ekonomis lama. Dengan system pemasangan cepat dan mudah pompa yang digerakan oleh energy surya dapat menjadi solusi yang cepat dalam mengatasi kebutuhan air bagi masyarakat.

\subsection{Tujuan}

Merancang panel kontrol untuk pompa air dan motor pengerak arah solar cell.

\subsection{Perumusan Masalah}

Perancangan dan perencanaan haruslah di lakukan dengan baik, dimana perencanaan memiliki tujuan untuk dapat mempermudah proses pengerjaandalam perencanaan pada pembuatan PLTS untuk penggerak pompa.

Berdasarkan hal tersebut maka permasalahannya adalah :

a. Menentukan panel kontrol untuk pompa air.

b. Menentukan panel kontrol untuk penggerak solar sell.

\subsection{Batasan masalah}

Pembahasan dalam tulisan ini adalah pembuatan PLTS untuk penggerak dan penyuplai energy pada pompa air. Batasan masalahnya sebagai berikut :

a. Menentukan bahan untuk perancangan control panel.

b. Menentukan kapasitas pompa air yang akan digunakan.

c. Merancang control panel untuk pompa air dan merancang control panel untuk penggerak motor solar cell.

1.4 Menjelaskan prinsip kerja dari control panel untuk pompa air.

1.5 Metode

a. Study literature 
Digunakan untuk mempelajari dan memahami prinsip dasar pemanfaatan energy surya untuk penggerak pompa air.

b. Perencanaan alat

Perencanaan yang dilakukan di lakukan dengan memperhitungkan posisi kegunaan efektivitas dari alat itu sendiri sesuai dengan rancangan akan dibuat nantinya.

c. Pembuatan

Pembuatan alat di lakukan berdasarkan data dan kondisi lapangan tempat dimana alat akan di buat dan di letakan.

d. Pengujian

Meliputi pengujian setiap kegiatan disesuaikan dengan perencanaan dan pembuatan yang dilakukan sesuai data hasil pengujian analisis dan disimpulkan.

\subsection{Sistimatik Laporan}

Dalam pembahasan dilakukan dengan membagi tiap-tiap bab sebagai berikut :

\section{PENDAHULUAN}

BAB I merupakan pendahuluan yang terdiri dari latar belakang,tujuan penelitian kelompok dan pembahasan landasan teori dan mode penelitian dan sistematika laporan.

\section{LANDASAN TEORI}

Menjelaskan tentang teori dasar berdasarkan filosofi yang telah ada, dan membahas latar belakang teknik serta komponen yang digunakan.

\section{PERENCANAAN DAN PEMBUATAN}

ALAT

Menjelaskan prinsip kerja alat dan komponen berupa solar cell, inverter, motor dan pengontrolan dan komponen pendukung lainnya.

\section{ANALISA DAN HASIL}

Merupakan BAB pokok permasalahan yang mengemukakan kesimpulan dan sran-saran penelitian dan percobaan yang dilakukan.

\section{KESIMPULAN DAN SARAN}

Merupakan rangkuman dari hasil uji coba.

\section{LANDASAN TEORI}

\subsection{Sel Surya}

\subsection{Sel Surya}

Sel surya pada dasarnya adalah suatu elemen aktif yang mengubah cahaya matahari menjadi energy listrik. Pada umumnya satu keeping sel surya mempunayai ketebalan $3 \mathrm{~mm}$, tersusun atas kutup positif dan negatif yang terbuat dari irisan bahan semikonduktor. Prinsip kerja suatu sel surya adalah dengan memanfaatkan efek fotovaltaik, yaitu suatu efek yang dapat mengubah secara langsung cahaya matahari menjadi suatu energy listrik.

Efek fotovoltaik ini ditemukan oleh Becquerel pada tahun 1839, dimana Becquerel mendeteksi adanya tegangan foto ketika sinar matahari mengenai elektroda pada larutan elektrolit. Alat ini digunakan secara individual sebagai alat pendeteksi cahaya pada kamera maupun digabung seri maupun paralel untuk memperoleh suatu harga tegangan listrik yang dikehendaki sebagai pusat penghasil tenaga listrik. Bahan dasar silicon ini terbuat dari silikon berkristal tunggal. Yaitu bahan yang sering digunakan untuk pembuatan jenis semikonduktor. Silicon dimurnikan hingga membentuk suatu unsur pembentuk atom sehingga dapat digunakan sebagai bahan sel surya. Dengan terbentuknya sifat atom pada setiap sel dari sel surya tersebut maka terbentuk pula suatu elektromagnetik yang menyebabkan efek photovoltaic.

Sel silikon di dalam solar cells panel yang disinari matahari/ surya, membuat photon bergerak menuju electron dan menghasilkan arus dan tegangan listrik. Sebuah sel silikon menghasilkan kurang lebih tegangan 0.5 Volt. Jadi sebuah panel surya 12 Volt terdiri dari kurang lebih 36 sel surya (untuk menghasilkan 17 Volt tegangan maksimun). Umumnya menghitung maksimum sinar matahari yang diubah menjadi tenaga listrik sepanjang hari adalah lima jam. Misalnya solar cells panel module memiliki kapasitas output: Watt hour. Solar cell 50 WP $12 \mathrm{~V}$, memberikan output daya sebesar $50 \mathrm{Watt}$ per hour dan tegangan adalah 12 Volt. Untuk perhitungan daya yang dihasilkan per hari adalah 50 Watt x 5 jam (maximun peak intensitas matahari). Panel surya tersebut dapat dilihat pada gambar 2.1.

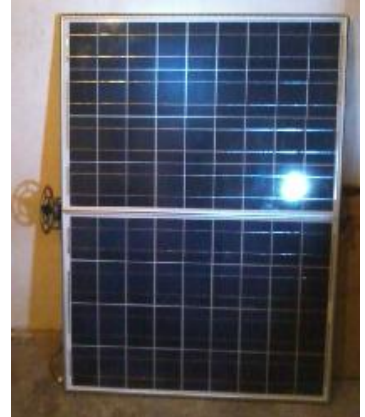

Gambar 2.1 Panel Surya.

\subsubsection{Jenis Solar Cell}

Jenis solar cell yang sering digunakan pada saat sekarang ini adalah sebagai berikut:

a. Polikristal (Poly-crystalline)

Merupakan panel surya / solar cell yang memiliki susunan kristal acak. Type Polikristal memerlukan luas permukaan yang lebih besar dibandingkan dengan jenis monokristal untuk menghasilkan daya listrik yang sama, akan tetapi dapat menghasilkan listrik pada saat mendung.

b. Monokristal (Mono-crystalline)

Merupakan panel yang paling efisien, menghasilkan daya listrik persatuan luas yang paling tinggi. Memiliki efisiensi sampai dengan 
15\%. Kelemahan dari panel jenis ini adalah tidak akan berfungsi baik ditempat yang cahaya mataharinya kurang (teduh), efisiensinya akan turun drastis dalam cuaca berawan.

\subsubsection{Prinsip Kerja Solar Cell}

Cara kerja sel surya adalah dengan memanfaatkan teori cahaya sebagi partikel. Sebagaimana diketahui bahwa cahaya baik yang tampak maupun yang tidak tampak memiliki dua buah sifat yaitu dapat sebagi gelombang dan dapat sebagi partikel yang disebut dengan Photon.

Beberapa solar panel di-paralel-kan untuk menghasilkan arus listrik yang lebih besar. Combiner pada gambar 2.2 menghubungkan kaki positif panel surya satu dengan panel surya lainnya. Kaki/ kutub negatif panel satu dan lainnya juga dihubungkan. Ujung kaki positif panel surya dihubungkan ke kaki positif charge controller, dan kaki negatif panel surya dihubungkan ke kaki negatif charge controller. Untuk menghidupkan beban perangkat AC (alternating current) seperti Televisi, Radio, komputer, dll, arus baterai disupply oleh inverter seperti yang terlihat pada gambar 2.2.

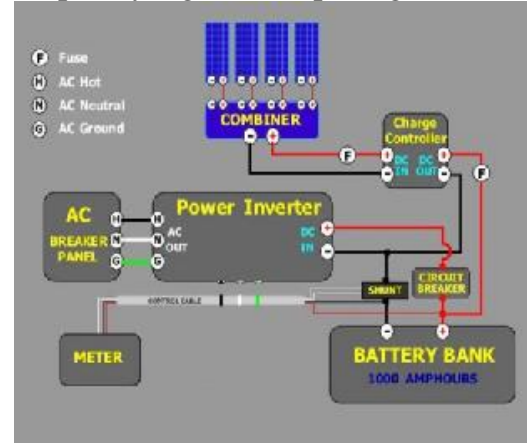

Gambar 2.2 Prinsip kerja solar cell

(Sumber : http:// Solar Water Pump

System (Pompa Air Tenaga Surya) _ Peaceful of My Life).

\subsection{Charge Controller (Regulator)}

Charge Controller adalah peralatan elektronik yang digunakan untuk mengatur arus searah yang diisi ke baterai dan diambil dari baterai ke beban. Solar charge controller mengatur overcharging (kelebihan pengisian - karena batere sudah 'penuh') dan kelebihan voltase dari solar module. Kelebihan voltase dan pengisian akan mengurangi umur baterai. Charge controller menerapkan teknologi Pulse width modulation $(P W M)$ untuk mengatur fungsi pengisian baterai dan pembebasan arus dari baterai ke beban. Solar module 12 Volt umumnya memiliki tegangan output 16 - 21Volt. Jadi tanpa solar charge controller, baterai akan rusak oleh over-charging dan ketidakstabilan tegangan. Baterai umumnya dicharge pada tegangan $14-14.7$ Volt dapat dilihat pada gambar 2.3. Change controller memiliki beberapa fungsi sebagai berikut: a. Mengatur Mengatur arus untuk pengisian ke baterai, menghindari overcharging, dan overvoltage.

b. Arus yang dibebaskan / diambil dari baterai agar baterai tidak 'full discharge', dan overloading.

c. Monitoring temperatur baterai.

Dalam memilih charge controller, harus memperhatikan hal-hal sebagai berikut:

a. Voltage 12 Volt DC / 24 Volt DC

b. Kemampuan (dalam arus searah) dari controller. Misalnya 5 Ampere, 6 Ampere, dan 10 Ampere.

c. Full charge dan low voltage cut.

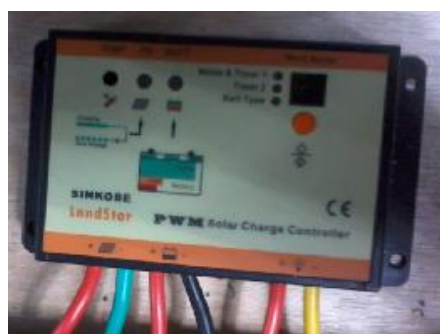

\subsection{Baterai atau Aki}

Gambar 2.3 Solar Charge Controller.

Baterai adalah alat yang menyimpan daya yang dihasilkan oleh panel surya yang tidak segera digunakan oleh beban. Daya yang disimpan dapat digunakan saat periode radiasi matahari rendah atau pada malam hari. Komponen baterai kadang-kadang dinamakan akumulator (accumulator).

Baterai memenuhi dua tujuan penting dalam sistem fotovoltaik, yaitu untuk memberikan daya listrik kepada sistem ketika daya tidak disediakan oleh array panel-panel surya, dan untuk menyimpan kelebihan daya yang ditimbulkan oleh panel-panel setiap kali daya itu melebihi beban. Baterai tersebut mengalami proses siklus menyimpan dan mengeluarkan, tergantung pada ada atau tidak adanya sinar matahari. Selama waktu adanya matahari, array panel menghasilkan daya listrik. Daya yang tidak digunakan dengan segera dipergunakan untuk mengisi baterai. Selama waktu tidak adanya matahari, permintaan daya listrik disediakan oleh baterai. Baterai yang cocok digunakan untuk PV adalah baterai deep cycle lead acid yang mampu menampung kapasitas $100 \mathrm{Ah}$, $12 \mathrm{~V}$, dengan efisiensi sekitar 80\%. Waktu pengisian baterai/aki selama 12 jam - 16 jam. Batrai yang digunakan dapat dilihat pada gambar 2.4.

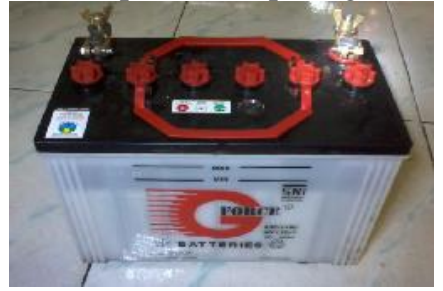




\subsection{Inverter}

Gambar 2.4 Baterai atau Aki

Inverter adalah perangkat elektronika yang dipergunakan untuk mengubah tegangan DC (Direct Current) menjadi tegangan AC (Alternating Curent). Output suatu inverter dapat berupa tegangan AC dengan bentuk gelombang sinus (sine wave), gelombang kotak (square wave) dan sinus modifikasi (sine wave modified). Sumber tegangan input inverter dapat menggunakan battery, tenaga surya, atau sumber tegangan DC yang lain.

Sumber DC yang dibutuhkan inverter dapat berasal dari baterai atau dari sumber tegangan AC yang disearahkan.Untuk mendapatkan keluaran yang dikehendaki maka digunakan rangkaian kontrol. Rangkaian kontrol tersebut antara lain berfungsi untuk mengatur frekuensi dan amplitudo gelombang keluaran. Agar gelombang keluarannya dapat kembali mendekati gelombang sinus, maka digunakan filter. Filter berfungsi untuk melewatkan frekuensi yang diharapkan saja. Filter yang digunakan disini biasanya merupakan filter jenis bandpass filter yang akan menangkal frekuensi rendah dan frekuensi tinggi yang tidak diharapkan pada keluarannya. Keluaran dari inverter mode saklar ini masih berupa pulsa-pulsa berfrekuensi tinggi (frekuensi switching) Sedangkan rangkaian kontrol berfungsi untuk mengendalikan proses penyaklaran (switching) yang terjadi pada inverter mode saklar. Seperti yang terlihat pada gambar inverter 2.5.

Beberapa hal yang harus dipertimbangkan dalam memilih inverter, yaitu:

a. Kapasitas beban dalam Watt, usahakan memilih inverter yang beban kerjanya mendekati dengan beban yang hendak kita gunakan agar effisiensi kerjanya maksimal.

b. Input DC 12 Volt atau 24 Volt.

c. Sinewave ataupun square wave outuput AC.

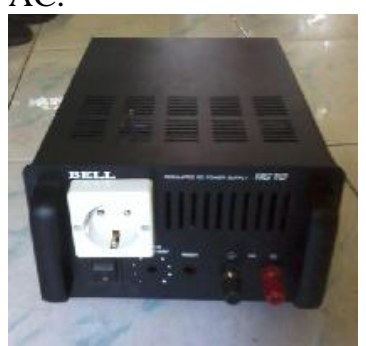

Gambar 2.5 Inverter.

2.6 Komponen-komponen kontrol panel 2.6.1. MCB

\section{a. Pengertian Mcb (Mini Circuit Breaker)}

MCB merupakan kependekan dari Miniature Circuit Breaker (bahasa Inggris). Biasanya MCB digunakan oleh pihak PLN untuk membatasi arus sekaligus sebagai pengaman dalam suatu instalasi listrik. MCB berfungsi sebagai pengaman hubung singkat (konsleting) dan juga berfungsi sebagai pengaman beban lebih.

MCB akan secara otomatis dengan segera memutuskan arus apabila arus yang melewatinya melebihi dari arus nominal yang telah ditentukan pada MCB tersebut. Arus nominal yang terdapat pada MCB adalah 1A, 2A, 4A, 6A, 10A, 16A, 20A, 25A, 32A dan lain sebagainya.

\section{b. Fungsi Mcb (Mini Circuit Breaker)}

Fungsi dari pemasangan Mini Circuit Breaker (MCB) adalah sebagai alat pengaman ataupun sebagai pembatas arus yang lewat pada saluran yang dimaksud. Mini Circuit Breaker (MCB) dipergunakan dan dipasang ada saluran awal sebelum saluran diberikan beban. Untuk MCB dengan kapasitas tertentu, semestinya memiliki kemampuan lepas dengan beban maksimal tertentu pula, tetapi kenyataan setelah diadakan suatu penelitian sebagai pembatas arus, MCB sering melepas arus melebihi kapasitas yang tertera pada alat tersebut, dapat dilihat pada gambar 2.6.
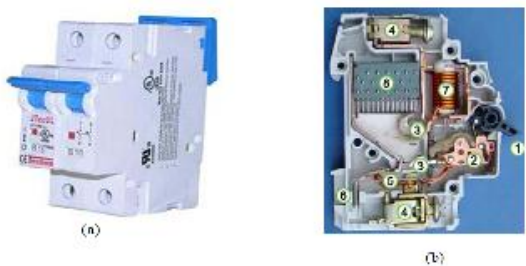

Gambar 2.6 Konstruksi MCB (a) dan Bagian-Bagian MCB (b)

(Sumber:http://duniatehnikku.wordpress.com/2011 /10/05/arti-dan-fungsi mcbmccb).

\subsubsection{Relay Omron}

a. Pengertian Relay

Relay adalah komponen elektronika berupa saklar elektronik yang digerakkan oleh arus listrik. Secara prinsip, relay merupakan tuas saklar dengan lilitan kawat pada batang besi (solenoid) di dekatnya. Ketika solenoid dialiri arus listrik, tuas akan tertarik karena adanya gaya magnet yang terjadi pada solenoid sehingga kontak saklar akan menutup. Pada saat arus dihentikan, gaya magnet akan hilang, tuas akan kembali ke posisi semula dan kontak saklar kembali terbuka.

Relay biasanya digunakan untuk menggerakkan arus atau tegangan yang besar (misalnya peralatan listrik 4 ampere AC $220 \mathrm{~V}$ ) dengan memakai arus atau tegangan yang kecil (misalnya 0.1 ampere 12 Volt DC).

Secara sederhana relay elektromekanis ini didefinisikan sebagai berikut:

- Alat yang menggunakan gaya elektromagnetik untuk menutup (atau membuka) kontak saklar. 
- Saklar yang digerakkan (secara mekanis) oleh daya/energi listrik.

Dalam pemakaiannya biasanya relay yang digerakkan dengan arus DC dilengkapi dengan sebuah dioda yang di-paralel dengan lilitannya dan dipasang terbaik yaitu anoda pada tegangan (-) dan katoda pada tegangan $(+)$.

Konfigurasi dari kontak-kontak relay ada dua jenis, yaitu:

- Normally Open (NO), artinya dalam keadaan normal relay tidak hubung (terbuka).

- Normally Closed (NC), artinya dalam keadaan normal relay terhubung.

\section{b. Prinsip Kerja Relay}

Relay terdiri dari Coil dan anak kontak, relay adalah gulungan kawat yang mendapat arus listrik, sedang anak kontak adalah sejenis saklar yang pergerakannya tergantung dari ada tidaknya arus listrik dicoil. Anak kontak relay ada 2 jenis : Normally Open (kondisi awal sebelum diaktifkan open), dan Normally Closed (kondisi awal sebelum diaktifkan close).

Secara sederhana prinsip kerja dari relay adalah ketika coil mendapat energi listrik maka akan timbul gaya elektromagnet yang akan menarik armature yang berpegas, dan anak kontak akan menutup NO menjadi NC dan NC akan menjadi NO dapat dilihat pada gambar 2.7 .

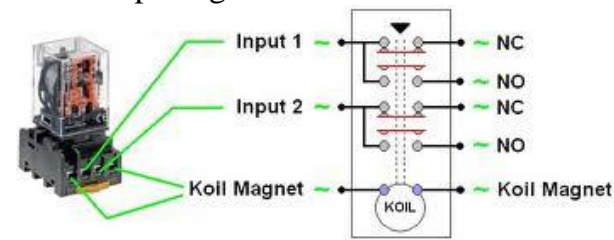

Gambar 2. 7 Relay Omron

(Sumber: http://my-smt.blogspot.com/2012/07/cara-

\subsubsection{Timer Omron} kerja-relay.html).

\section{a. Pengertian Timer}

Timer adalah menempatkan informasi sekitar waktu yang lewat pada rangkaian control. Control pemilihan waktu dapat dicapai dengan menggunakan komponen pneumatic, elektromekanis, atau elektronis. Perbedaan dapat dibuat antara timer (pemilih waktu) dengan relay tunda waktu. Umumnya relay tunda waktu adalah peranti yang mempunyai fungsi pemilihan waktu setelah kumparan timer telah diberi tenaga atau dihilangkan tenaganya. Timer yang digunakan pada alat ini adalah Timer OMRON H3BA dapat dilihat pada gambar 2.8.
Gambar 2. 8 Relay Omron H3BA

(sumber: http://TDR Time Delay Relay _ Timer.htm).

\section{b. Fungsi timer omron}

Fungsi dari peralatan kontrol ini adalah sebagai pengatur waktu bagi peralatan yang dikendalikannya. Timer ini dimaksudkan untuk mengatur waktu hidup atau mati dari kontaktor atau untuk merubah sistem bintang ke segitiga dalam delay waktu tertentu.

\subsubsection{Kabel Listrik}

Kabel listrik adalah salah satu media untuk menyalurkan arus listrik yang umumnya terbuat dari bahan isolator dan konduktor. Konduktor dapat terbuat dari logam tembaga, aluminiun, atau logam lain yang berfungsi sebagai media penghantar (conductor) energi listrik, sedangkan isolator berfungsi untuk melindungi kabel bersentuhan dengan kabel lain atau dengan manusia. Isolator dapat terbuat dari karet atau plastik, tergatung jenis kabel listrik dan pabrik pembuatnya.

Saat ini ada beberapa jenis kabel listrik yang diproduksi perusahaan-perusahan sesuai dengan fungsinya. Jumlah, warna, dan isolator yang digunakan pun cukup beragam. Pemahaman dasar tentang jenis kabel listrik ini perlu dikuasai sebelum memperdalam pengetahuan di bidang listrik dan elektronika. Ini dimaksudkan agar ketika merancang instalasi perkabelan listrik atau membuat wiring rangkaian elektronika, kabel yang digunakan akan tepat guna. Tidak terlalu besar, tidak terlalu kecil, dan yang jelas sesuai dengan kebutuhan. Contoh sederhana, ketika sahabat memasang antena televisi, tentu kabel yang digunakan adalah kabel antena coaxial, jika menggunakan kabel listrik NYY atau NYAF, maka sinyal televisi tidak akan tertangkap dengan sempurna meskipun harga kabel tersebut jauh lebih mahal. Contoh lain, untuk menjalankan pompa listrik 220 Volt/500 Watt digunakan kabel listrik jenis NYY atau NGA karena jika menggunakan kabel LAN (UTP) atau kabel coaxial, kemungkinan akan terbakar karena terlalu panas.

Berikut adalah beberapa jenis kabel listrik yang sering digunakan:

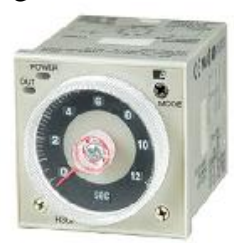




\section{a. Kabel NYA}

Kable NYA umumnya dipakai pada instalasi perumahan dengan daya menengah ke bawah karena harganya reltif murah. Kabel ini disebut juga kabel tunggal karena intinya hanya satu yang dilapisi isolator PVC. Warna standar pada kabel ini adalah merah, hitam, biru, kuning, dan kuning-hijau. Kabel ini mudah sekali cacat dan mudah digigit tikut, oleh karena itu ketika melakukan instalasi perkabelan harus benar-benar diperhatikan cara penyambungan dan jarak antara kabel yang berbeda polaritas. Untuk tujuan keamaman biasanya petugas instalatir listrik memasang kabel NYA di dalam pipa untuk menghindari gisitan tikus dan gangguan fisik lain dapat dilihat pada gambar 2.11.

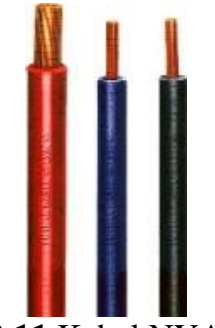

Gambar 2.11 Kabel NYA.

(sumber: http:// Jenis-jenis kabel listrik yang perlu diketahui dan dipahami.htm).

\section{b. Kabel NYM}

Kabel NYM memiliki lapisan isolator PVC dua lapis berwarna putih dan abu-abu yang terdiri dari 2 sampai 4 kabel di dalamnya. Dari segi keamanan kabel ini relatif lebih tahan luka/cacat dibanding kabel NYA dan harganya pun lebih mahal dari kabel NYA. Kabel ini dapat dipergunakan di lingkungan kering dan basa tetapi tidak dianjurkan untuk ditanam di dalam tanah dapat dilihat pada gambar 2.12.

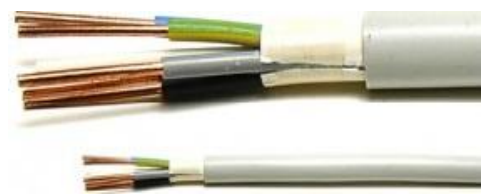

Gambar 2.12 Kabel NYM.

(sumber: http:// Jenis-jenis kabel listrik yang perlu diketahui dan dipahami.htm).

\section{c. Kabel NYAF}

Kabel NYAF mempunyai isolator tebal dari bahan PVC. Kabel ini cukup lentur karena di dalamanya terdiri dari kabel serabut yang disusun per kelompok. Kabel NYAF digunakan untuk instalasi perangkat-perangkat elektronik dan listrik yang membutuhkan fleksibilitas tinggi. Contoh penggunaan kabel ini dapat dilihat pada panel kontrol telekomunikasi, rectifier, inverter, DCPDB, Sentral Telepon Digital, Battery, dan Panel Transmisi dapat dilihat pada gambar 2.13.

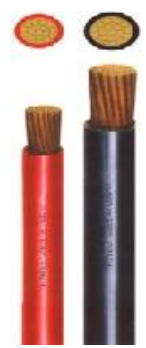

Gambar 2.13 Kabel NYAF.

(sumber: http:// Jenis-jenis kabel listrik yang perlu diketahui dan dipahami.htm).

\subsubsection{Lampu Tanda atau Lampu Indicator.}

Lampu tanda atau indicator merupakan lampu tanda yang sering dipakai pada panel daya ataupun panel control. Lampu ini dimanfaatkan untuk penandaan bagian yang aktif, misalkan pada panel control dimanfaatkan untuk penandaan bagian control yang sedang aktif, ataupun dalam panel daya dimanfaatkan unutk penandaan bagian fasa yang sedang aktif dapat dilihat pada gambar 2.15.

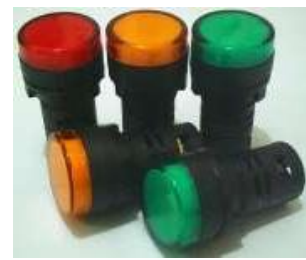

Gambar 2.15 Lampu indicator panel (sumber: http://lampu indicator panel.htm).

\subsubsection{Push Button}

\section{a. pengertian push button}

Push button adalah peralatan listrik yang berfungsi sebagai saklar impuls yang berfungsi dalam rangkaian listrik Push button ada dua macam, yaitu push button on dengan warna hijau yang bekerja dengan normally open dan push button off yang berwarna merah yang bekerja normally close pada rangkaian kontrol.

\section{b. jenis-jenis push button}

- Tombol Push button ON

tombol sebagai saklar yang akan digunakan sebagai peng-ON dipanel dan tombol inilah yang akan dipakai sehari-hari apbila panel atau rangkaian itu akan digunakan dapat dilihat pada gambar 2.16 


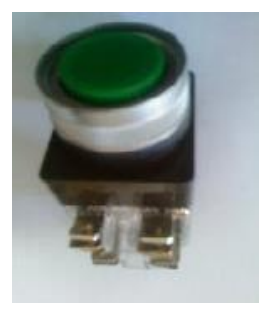

Gambar 2.16 Push Button

(sumber: http:// saklar push button.htm).

\subsubsection{Selector Switch}

Selector Switch, alat ini di gunakan untuk memilih,banyak sekali type selector switch, tapi biasanya hanya dua type yang sering di gunakan, yaitu 2 posisi, (ON-OFF/Start-Stop/0-1) dan 3 posisi (ON-OFF-ON/Auto-Off-Manual)dengan selector switch, kondisi peralatan dapat langsung di ketahui dari penunjukan tangkai selector switch, dengan selector switch, rangkaian ON-OFF lebih sederhana, karena selector switch tidak seperti tombol tekan yang hanya kontak sementara dapat dilihat pada gambar 2.18 .

Gambar 2.18 Selector Switch

(sumber: http:// dunia listrik dan elektronika selector switch.htm)

Jika kontrol yang kita buat menggunakan 2 mode (auto dan manual) atau 3 mode(auto, off dan manual), selector switch bisa kita gunakan dapat dilihat pada gambar 2.19.

Gambar 2.19 Selector Switch 2 Posisi (sumber: http:// dunia listrik dan elektronika selector switch.htm).

\subsubsection{Ampere Meter}

\section{a. pengertian ampere meter}

Amperemeter adalah alat yang digunakan untuk mengukur kuat arus listrik. Umumnya alat ini dipakai oleh teknisi elektronik dalam alat multi tester listrik yang disebut avometer gabungan dari fungsi amperemeter, voltmeter dan ohmmeter.

\section{b. Fungsi ampere meter}

Amper meter dapat dibuat atas susunan mikroamperemeter dan shunt yang berfungsi untuk deteksi arus pada rangkaian baik arus yang kecil, sedangkan untuk arus yang besar ditambhan dengan hambatan shunt.

\section{c. Prinsip kerja ampere meter}

Amperemeter bekerja sesuai dengan gaya lorentz gaya magnetis. Arus yang mengalir pada kumparan yang selimuti medan magnet akan menimbulkan gaya lorentz yang dapat menggerakkan jarum amperemeter. Semakin besar arus yang mengalir maka semakin besar pula simpangannya.

\subsubsection{Volt Meter}

Voltmeter adalah suatu alat yang berfungsi untuk mengukur tegangan listrik. Dengan ditambah alat multiplier akan dapat meningkatkan kemampuan pengukuran alat voltmeter berkali-kali lipat. Gaya magnetik akan timbul dari interaksi antar medan magnet dan kuat arus. Gaya magnetic tersebut akan mampu membuat jarum alat pengukur voltmeter bergerak saat ada arus listrik. Semakin besar arus listrik yang mengelir maka semakin besar penyimpangan jarum yang terjadi.

\section{PERANCANGAN DAN PEMbUATAN ALAT}

\subsection{Definisi Pompa Air Sel Surya}

Pompa air dengan menggunakan sumber energi sel surya, merupakan suatu terobosan sistem pemompaan yang mana mulai banyak dijumpai di daerah Indonesia. Pompa air Sel Surya mendapatkan sumber energi dari matahari yang jatuh pada diode silicon (silikon cell) yang menghasilkan photon, secara konstan yang akan menghasilkan energi berkisar \pm 0.5 volt - max. $600 \mathrm{mV}$ pada 2 ampere.

Energi listrik yang dihasilkan akan disalurkan ke baterai charger yang mengontrol arus yang menuju accumulator, jika level tegangan yang ditentukan itu telah tercapai, maka arus pengisian akan turun secara otomatis ke level yang aman tepatnya yang telah ditentukan dan menahan arus pengisian hingga menjadi lebih lambat sehingga indicator menyala menandakan baterai telah terisi penuh.

\subsection{Ketentuan Pembuatan Pompa Air Solar Cell}

\subsubsection{Fungsi Pompa Air Solar Cell}


NC, keluaran dari anak kontak R1 NC dihubungkan ke coil T1.

Dari keluaran anak kontak R2 NCtadi dihubungkan ke anak kontak T1 NO, keluaran dari anak kontak T1 NO dihubungkan ke anak kontak T2 NC, keluaran dari anak kontak T2 NC dihubungkan ke coil R1. Keluaran dari anak kontak R2 NC tadi dihubungkan anak kontak R1 NO dihubungkan ke keluaran anak kontak T1 NO tadi dan dihubungkan ke coil R2. Dari keluaran anak kontak R2 NC tadi dihubungkan ke anak kontak R1 $\mathrm{NO}$, keluaran dari anak kontak R1 NO dihubungkan ke coil T2.

Dari keluaran MCB tadi dihubungkan anak kontak R2 NC, keluaran dari anak kontak NC dihubungkan ke coil T3. Dari masuk R2 NC di hubungkan ke anak kontak T3 NO, keluaran dari anak T3 NO dihubungkan ke coil R3. Dari masuk anak kontak T3 NO dihubungkan ke anak kontak R3 NO, keluaran dari anak kontak R3 NO dihubungkan ke keluaran T3 NO dan dihubungkan ke anak kontak T4 NC, keluran dari anak kontak T4 NC dihubungkan ke coil R4.

Dari masukan anak kontak R3 NO tadi dihubungkan ke anak kontak R3 NO, keluaran dari anak kontak R3 NO di hubungkan ke coil T4.Untuk sumber negatif rangkaian dihubungkan pada semua coil negatif relay, dan semua coil negatif dari timer.

\subsubsection{Rangkaian Daya.}

Pada rangkain daya panel kontrol pengerak solar cell ini menggunakan aki sebagai sumber teganganya. Karena menggunakan motor wiper bertegangan DC untuk penggerak solar sell tersebut. Untuk gambar rangkaian dayanya bisa di lihat pada lapiran empat. Cara pemasangan rangkaian dayanya pertama hubungkan terminal positif aki ke MCB, MCB yang digunakan adalah 4 amper. Dari keluaran MCB dihubungkan ke anak kontak R2 NO, keluaran dari anak kontak R2 NO di hubungkan ke keluaran anak kontak R4 NO dan di hubungkan ke terminal negatif motor wiper.

Dari masuk anak kontak R2 NO tadi dihubungkan ke anak kontak R4 NO, keluaran dari anak R4 NO dihubungkan ke terminal positif motor wiper. untuk sumber negatif hubungakan terminal positif aki ke anak kontak R2 NO, keluaran dari anak kontak R2 NO dihubungkan ke keluaran anak kontak R4 NO dank e positif motor wiper. Dari masukan anak kontak R2 NO tadi dihubungakan ke anak kontak R4 NO, keluaran anak kontak R4 NO dihubungkan ke keluaran anak kontak R2 NO dan ke terminal negatif motor wiper.

\section{PENGUJIAN DAN PEMBAHASAN \\ 4.1. Fungsi Panel Kontrol \\ 4.1.1 Panel Kontrol Pompa Air.}

Kontrol panel pompa air yang terpasang pada alat ini berfungsi sebagai pengatur hidup motor bergantian secara otomatis dan manual. Pada kontrol panel tersebut terdapat rangkaian kontrol dan rangkaian daya pompa air, dimana rangkaian daya pompa air berguna sebagai penyalur daya dari sumber masuk ke pompa air. Sedangkan rangkaian kontrol berguna sebagai pengatur operasional pompa air. Jika terdapat salah satu kesalahan dalam kontrol panel tersebut, tentunya akan berpengaruh terhadap kinerja dari pompa air.

Rangkaian kontrol pompa air ini memiliki dua sistem operasi yaitu yang pertama, sistem otomatis yang menggunakan relay sebagai pemutus dan penyambung arus menuju ke pompa. Dan timer yang berfungsi untuk membatasi waktu atau durasi pergantian relay beroperasi. Kedua, sistem manual dengan menggunakan push button biasa untuk pemutus dan penyambung arus menuju ke pompa. Sedangkan untuk pengatur sistem tersebut digunakan selector swith.

\subsubsection{Panel Kontrol Penggerak Solar Cell}

Kontrol panel penggerak solar sell yang dioperasikan pada alat ini memiliki peranan penting dalam mendukung keefektifan penyerapan energy cahaya matahari. Kontrol panel tersebut didesain untuk menggerakkan modulator penangkap energy cahaya matahari dengan baik, dimana modulator solar sell ini dirancang agar dapat mengikuti pergerakan cahaya matahari dari timur ke barat. Dengan bergeraknya modulator mengikuti arah cahaya matahari, diperkirakan akan dapat menangkap energy cahaya matahari secara optimal.

Didalam panel kontrol penggerak solar cell, dipasangkan dua jenis rangkaian elektromagnetik yaitu pertama, rangkaian daya penggerak solar sell. Rangkaian ini difungsikan sebagai penggerak motor wiper pengatur posisi modulator menuju arah datangnya cahaya matahari. Kedua, rangkaian kontrol penggerak solar sell yang digunakan untuk pengendalikan pergerakan modulator solar sell secara teratur dan dengan limit yang tepat.

Rangkaian kontrol penggerak solar sell ini bersifat otomatis, maka dapat mengurangi campur tangan manusia dalam penggoperaisan solar sell. Dengan sifatnya yang otomatis dibutuhkan komponen elektromagmetik berupa relay dan timer, dimana relay disini berfungsi untuk memutus dan menyambungkan arus. Dan timer digunakan 
sebagai pengatur waktu atau durasi operasi dari relay, sehingga sesuai dengan yang diinginkan. 
arah ( dari timer ke barat) selama waktu yang diset pada timer 4 .

\section{b. Prinsip Kerja Rangkain Daya}

Prinsip kerja rangkaian daya pada panel solar cell menggunaka prinsip kerja rangkaian motor bolak balik putaran. Dimana motor wiper akan berputar mengikuti cahaya matahari ketika R2 ON, dan motor wiper akan berputar berlawan arah (dari barat ke timur) ketika R4 ON.

\subsection{Perhitungan Panel}

\subsubsection{Perhitungan Ratting MCB}

Dari keseluruhan beban yang kita pakai maka didapatkan total daya adalah 200,8 watt, maka dapat digunakan rumus perhitungan sebagai berikut:

$$
\begin{gathered}
\mathrm{I}=\frac{\mathrm{p}}{\text { diberikan nilai }=0,8)} \\
\mathrm{V} \times \sqrt{3} \times \cos \varphi \\
\mathrm{I}=\frac{200,8}{220 \times \sqrt{3} \times 0,8} \\
\mathrm{I}=\frac{200,8}{304,84} \\
\mathrm{I}=0,65 \mathrm{~A} .
\end{gathered}
$$

Dari perhitungan yang didapatkan maka MCB yang di gunakan adalah $2 \mathrm{~A}$.

\subsubsection{Perhitungan Panghantar}

Total keselurahan beban yang di pakai pada panel ini adalah 200,8 watt, maka digunakan rumus sebagai berikut:

$$
\begin{aligned}
& \begin{array}{l}
\mathrm{I}=\frac{\mathrm{p}}{\text { diberikan nilai }=0,8)} \\
\mathrm{V \times \operatorname {Cos } \varphi}
\end{array} \\
& \mathrm{I}=\frac{200,8}{220 \times 0,8}(\mathrm{Cos} \\
& \mathrm{I}=\frac{200,8}{176} \\
& \mathrm{I}=1,14 \mathrm{~A} .
\end{aligned}
$$

Dari hasil perhitungan arus nominal pada panel adalah 1,14 A. Dari arus nominal tersebut diperoleh KHA penghantar yang lihat pada sumber PUIL 2000 maka digunakan rumus sebagai berikut:

$$
\begin{aligned}
\mathrm{KHA} & =115 \% \times \mathrm{In} \\
\mathrm{KHA} & =115 \% \times 1,14 \\
& =13,11 \text { ampere. }
\end{aligned}
$$

Berdasarkan tabel KHA maka didapatkan besar ukuran pengantar yang digunakan minimal adalah NYAF $1 \mathrm{~mm}^{2}$. Jika digunakan penghantar terlalu kecil akan menyebabkan penghantar tersebut akan panas saat digunakan. Hal ini berdasarkan dari pertimbangan beban, dapat dilihat pada tabel 4.1 berikut ini.

Tabel 4.1. Kemampuan Hantar Arus.

Tabel Kemampuan Hantar Arus

\begin{tabular}{|l|c|c|}
\hline No & $\begin{array}{c}\text { Penampang Kabel } \\
\left(\mathbf{m m}^{2}\right)\end{array}$ & $\begin{array}{c}\text { Kemampuan membawa Arus } \\
\text { (Ampere })\end{array}$ \\
\hline 1. & 0,75 & 12 \\
\hline 2. & 1 & 15 \\
\hline 3. & 1.5 & 13 \\
\hline 4. & 25 & 25 \\
\hline 5. & 4 & 34 \\
\hline 6. & 5 & 44 \\
\hline 7. & 10 & 61 \\
8. & 16 & 82 \\
\hline 9. & 25 & 108 \\
\hline 10. & 35 & 135 \\
11. & 50 & 168 \\
\hline 12 & 70 & 2017 \\
\hline 13. & 95 & 250 \\
14. & 120 & 292 \\
\hline
\end{tabular}

Sumber: Katalog igus chainflex terbitan tahun 2009

\subsection{Membandingkan Hasil Volume Air}

Pada pengujian untuk mengetahui volume air yang dihasilkan digunakan ember dengan kapasitas 13 liter. 13 liter dihasilkan pompa air dalam 20 s, maka Volume air permenit adalah sebagai berikut:

$$
\begin{aligned}
& \text { Volume air }=13 / 20=0,65 \mathrm{~L} / \mathrm{s} . \\
& \text { Is }=0,65 \text { X } 60=39 \mathrm{~L} / \text { menit. }
\end{aligned}
$$

Jika penampung air yang digunakan $500 \mathrm{~L}$, maka diperlukan waktu pengisian sebagai berikut:

$500 / 0,65=769,23 \mathrm{~s} .=12,8$ menit.

Jadi waktu yang di perlukan dalam mengisi tempat penampungan 500 liter tersebut adalah 12,8 menit.

\subsection{Pengujian ketahanan Aki terhadap Beban}


Pengujian ini dilakukan untuk mengetahui berapa lama ketahanan aki terhadap beban yang digunakan tanpa pengecesan dengan solar cell dan ketahanan aki terhadap beban dengan dilakukan pengecasan(charger). Pengujian dilakukan dengan menggunakan beban pompa air. Lama ketahanan aki, dapat dilihat pada saat terjadi penurunan tegangan setiap waktu.

\subsubsection{Pengujian tanpa Pengecesan}

Pada pengujian ini battrai yang digunakan dalam keaadaaan kurang baik. Tegangan battrai pada saat pengujian adalah 11,8V. Setiap lima menit tegangan pada aki hampir tidak mengalami penurunan. Dimana hasilnya dapat dilihat pada tabel 4.3.

Tabel 4.3. ketahanan aki tanpa pengecasan

\begin{tabular}{|c|c|c|c|}
\hline No. & waktu(menit) & tegangan(V) & $\begin{array}{c}\text { Output } \\
(\mathbf{A})\end{array}$ \\
\hline 1 & 5 & 11.7 & 16.5 \\
\hline 2 & 10 & 11.6 & 16.5 \\
\hline 3 & 15 & 11.6 & 16.5 \\
\hline 4 & 20 & 11.6 & 16.5 \\
\hline 5 & 25 & 11.6 & 16.5 \\
\hline 6 & 30 & 11.5 & 16.5 \\
\hline
\end{tabular}

Sumber: Pengujian pada tanggal 23 Oktober 2013

Dari tabel 4.3, batrai turun setelah 30 menit. Jadi waktu ketahanan batrai terhadap beban cukup lama. Tegangan batrai tetap selama 20 menit seperti yang terlihat pada gambar 4.7

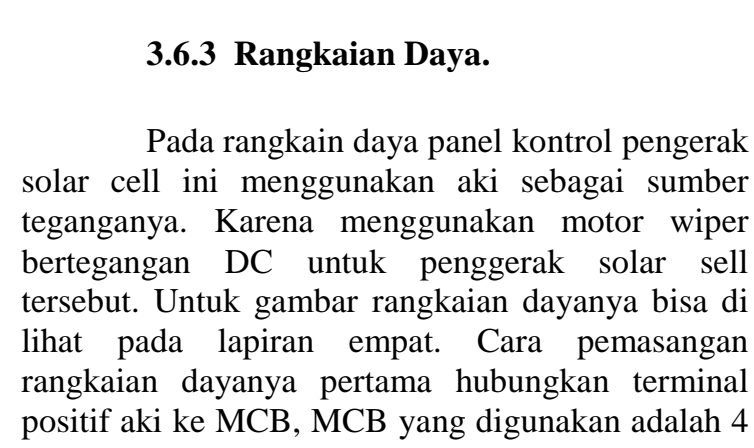

\footnotetext{
Gambar 4.7 Grafik tegangan setiap waktu tanpa pengecasan
}

Dengan keluaran atau pemakai aki setiap jam 16.5 A maka ketahanan aki terhadap beban adalah sebagai berikut:

Ketahanan aki $=100 / 16.5=6.06$ jam

Jika aki hanya mempunayai kemampuan $80 \%$ maka ketahanan aki selama dibebani adalah sebagai berikut:

\subsubsection{Pengujian sambil Pengecasan}

Pada pengujian ini battrai yang digunakan dalam keaadaaan bagus atau full. Tegangan battrai pada saat pengujian adalah $12 \mathrm{~V}$ dc. Setiap sepuluh menit tegangan pada aki tidak mengalami penurunan. Dimana hasilnya dapat dilihat pada tabel 4.4.

Tabel 4.4 Ketahanan aki sambil pengecasan

\begin{tabular}{|c|c|c|c|}
\hline No. & waktu(menit) & tegangan(V) & $\begin{array}{c}\text { Output } \\
(\mathbf{A})\end{array}$ \\
\hline 1 & 10 & 11.5 & 16.5 \\
\hline 2 & 20 & 11.5 & 16.5 \\
\hline 3 & 30 & 11.5 & 16.5 \\
\hline 4 & 40 & 11.5 & 16.5 \\
\hline 5 & 50 & 11.7 & 16.5 \\
\hline 6 & 60 & 11.7 & 16.5 \\
\hline
\end{tabular}

Sumber: Pengujian pada tanggal 24 Oktober 2013

Dari tabel 4.4 tegangan pada aki saat diberi beban tidak mengalami kekurangan tegangan, bahkan tegangan semakin bertambah pada saat menit ke 50 dan 60. Dimana grafik tegangan setiap waktu dapat dilihat pada gambar 4.4.

\section{tegangan(V)}

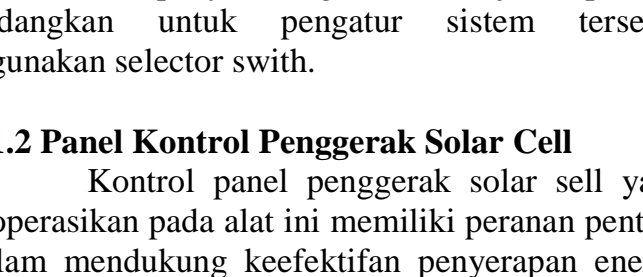

Gambar 4.8. grafik tegangan setiap waktu sambil pengecasan

Dari gambar 4.8, ketahanan aki dalam sejam tidak berpengaruh saat pemakaian beban bahkan tegangan aki menjadi naik. Jadi aki dapat bertahan lama dibandingkan tidak dicharger. Pada pengujian ini arus yang keluar dari aki adalah 16.5 A dan arus yang masuk jika intensitas cahaya matahari tinggi atau keadaan cerah adalah kurang lebih 10 A. Jadi arus yang keluar perjam gadalah 6.5 A. Untuk menentukan berapa lama ketahanan aki adalah sebagai berikut:

Jika aki hanya mempunayai kemampuan $80 \%$ maka ketahanan aki selama dibebani adalah sebagai berikut:

Ketahanan Aki $=100 / 6.5 * 80 \%=12,30$ jam

Dengan ketahanan aki lebih dari 12 jam, maka pemakaian aki sudah efektif untuk menggerakkan pompa air.

Dari semua pengujian yang dilakukan, penggunaan alat ini telah menghemat pemakain komponen dan bahan dari semua perencanaan yang telah dilakukan. Jadi alat ini bisa digunakan oleh masyarakat. 


\section{PENUTUP \\ 5.1 KESIMPULAN}

\subsection{KESIMPULAN}

Setelah melakukan pemasangan dan pengujian maka dapat disimpulkan sebagai berikut:

1. Panel bekerja sesuai dengan perencanaan yaitu dapat mengontrol dua pompa hidup bergantian secara otomatis dan manual, dengan menggunakan timer sebagai pewaktu.

2. Untuk mengoprasikan panel control untuk pompa air cara dengan manual, kita harus menekan push batton NO untuk Start, dan push batton NC untuk Off..

3. Prinsip kerja dari panel kontrol solar cell adalah untuk memutar solar sell menggikuti cahaya matahari, dengan menggunakan empat step putaran motor yang di atur waktunya oleh timer.

\subsection{Saran}

Panel dan soalr cell ini sangat baik digunakan pada sistim irigasi yang sulit untuk membuat waduk dan saluran pembawa.

Disarankan menggunakan komponenkomponen DC untuk melakukan pengontrolan. Karena pada saat melakukan pengoperasian sistim panel dan pompa kita tidak mengunakan Konverter lagi dan berpengaruh pada penghematan energy dan kinerja dari alat tersebut.

\section{DAFTAR PUSTAKA}

Hasan Hasnawiya. 2012. Perancangan Pembangkit Listrik Tenaga Surya di Pulau Saugi. Makasar: Jurnal Riset dan Teknologi Kelautan Volume 10.

http://energiterbarukanonline.blogspot.com/2012/10 /menghitung-kebutuhan-tenaga-surya.html. rabu, 28 agustus 201316.17 WIB.

http://jurnal.untad.ac.id/jurnal/index.php/SMARTE K/article/download/438/375.(24 Oktober 2013. Jam 9.

Pagliaro Mario, Giovanni Palmisano, dkk. 2008. Flexible Solar Cell. Italy: WILEY-VCH.

http://duniatehnikku.wordpress.com/2011/10/05 arti-dan-fungsi mcbmccb.

http://my-smt.blogspot.com/2012/07/cara-kerja relay.html.

http://bocahisonan.blogspot.com/2011/09/selector switch.html.

http:// Cara Kerja Relay - Mengenal Lebih Dekat SMT Yamaha.htm.

http:// DUNIA LISTRIK DAN ELEKTONIKA SELECTOR SWITCH.htm.

http:// /NONO HARYONO Timer_Penghitung waktu.htm.

http:// Prinsip Kerja Relay.htm.

http:// TDR Time Delay Relay _ Timer.htm. 


\section{PENUTUP \\ 5.1 KESIMPULAN}

\subsection{KESIMPULAN}

Setelah melakukan pemasangan dan pengujian maka dapat disimpulkan sebagai berikut:

1. Panel bekerja sesuai dengan perencanaan yaitu dapat mengontrol dua pompa hidup bergantian secara otomatis dan manual, dengan menggunakan timer sebagai pewaktu.

2. Untuk mengoprasikan panel control untuk pompa air cara dengan manual, kita harus menekan push batton NO untuk Start, dan push batton NC untuk Off..

3. Prinsip kerja dari panel kontrol solar cell adalah untuk memutar solar sell menggikuti cahaya matahari, dengan menggunakan empat step putaran motor yang di atur waktunya oleh timer.

\subsection{Saran}

Panel dan soalr cell ini sangat baik digunakan pada sistim irigasi yang sulit untuk membuat waduk dan saluran pembawa.

Disarankan menggunakan komponenkomponen DC untuk melakukan pengontrolan. Karena pada saat melakukan pengoperasian sistim panel dan pompa kita tidak mengunakan Konverter lagi dan berpengaruh pada penghematan energy dan kinerja dari alat tersebut.

\section{DAFTAR PUSTAKA}

Hasan Hasnawiya. 2012. Perancangan Pembangkit Listrik Tenaga Surya di Pulau Saugi. Makasar: Jurnal Riset dan Teknologi Kelautan Volume 10.

http://energiterbarukanonline.blogspot.com/2012/10 /menghitung-kebutuhan-tenaga-surya.html. rabu, 28 agustus 201316.17 WIB.

http://jurnal.untad.ac.id/jurnal/index.php/SMARTE K/article/download/438/375.(24 Oktober 2013. Jam 9.

Pagliaro Mario, Giovanni Palmisano, dkk. 2008. Flexible Solar Cell. Italy: WILEY-VCH.

http://duniatehnikku.wordpress.com/2011/10/05 arti-dan-fungsi mcbmccb.

http://my-smt.blogspot.com/2012/07/cara-kerja relay.html.

http://bocahisonan.blogspot.com/2011/09/selector switch.html.

http:// Cara Kerja Relay - Mengenal Lebih Dekat SMT Yamaha.htm.

http:// DUNIA LISTRIK DAN ELEKTONIKA SELECTOR SWITCH.htm.

http:// /NONO HARYONO Timer_Penghitung waktu.htm.

http:// Prinsip Kerja Relay.htm.

http:// TDR Time Delay Relay _ Timer.htm. 


\section{PENUTUP \\ 5.1 KESIMPULAN}

\subsection{KESIMPULAN}

Setelah melakukan pemasangan dan pengujian maka dapat disimpulkan sebagai berikut:

1. Panel bekerja sesuai dengan perencanaan yaitu dapat mengontrol dua pompa hidup bergantian secara otomatis dan manual, dengan menggunakan timer sebagai pewaktu.

2. Untuk mengoprasikan panel control untuk pompa air cara dengan manual, kita harus menekan push batton NO untuk Start, dan push batton NC untuk Off..

3. Prinsip kerja dari panel kontrol solar cell adalah untuk memutar solar sell menggikuti cahaya matahari, dengan menggunakan empat step putaran motor yang di atur waktunya oleh timer.

\subsection{Saran}

Panel dan soalr cell ini sangat baik digunakan pada sistim irigasi yang sulit untuk membuat waduk dan saluran pembawa.

Disarankan menggunakan komponenkomponen DC untuk melakukan pengontrolan. Karena pada saat melakukan pengoperasian sistim panel dan pompa kita tidak mengunakan Konverter lagi dan berpengaruh pada penghematan energy dan kinerja dari alat tersebut.

\section{DAFTAR PUSTAKA}

Hasan Hasnawiya. 2012. Perancangan Pembangkit Listrik Tenaga Surya di Pulau Saugi. Makasar: Jurnal Riset dan Teknologi Kelautan Volume 10.

http://energiterbarukanonline.blogspot.com/2012/10 /menghitung-kebutuhan-tenaga-surya.html. rabu, 28 agustus 201316.17 WIB.

http://jurnal.untad.ac.id/jurnal/index.php/SMARTE K/article/download/438/375.(24 Oktober 2013. Jam 9.

Pagliaro Mario, Giovanni Palmisano, dkk. 2008. Flexible Solar Cell. Italy: WILEY-VCH.

http://duniatehnikku.wordpress.com/2011/10/05 arti-dan-fungsi mcbmccb.

http://my-smt.blogspot.com/2012/07/cara-kerja relay.html.

http://bocahisonan.blogspot.com/2011/09/selector switch.html.

http:// Cara Kerja Relay - Mengenal Lebih Dekat SMT Yamaha.htm.

http:// DUNIA LISTRIK DAN ELEKTONIKA SELECTOR SWITCH.htm.

http:// /NONO HARYONO Timer_Penghitung waktu.htm.

http:// Prinsip Kerja Relay.htm.

http:// TDR Time Delay Relay _ Timer.htm. 


\section{PENUTUP \\ 5.1 KESIMPULAN}

\subsection{KESIMPULAN}

Setelah melakukan pemasangan dan pengujian maka dapat disimpulkan sebagai berikut:

1. Panel bekerja sesuai dengan perencanaan yaitu dapat mengontrol dua pompa hidup bergantian secara otomatis dan manual, dengan menggunakan timer sebagai pewaktu.

2. Untuk mengoprasikan panel control untuk pompa air cara dengan manual, kita harus menekan push batton NO untuk Start, dan push batton NC untuk Off..

3. Prinsip kerja dari panel kontrol solar cell adalah untuk memutar solar sell menggikuti cahaya matahari, dengan menggunakan empat step putaran motor yang di atur waktunya oleh timer.

\subsection{Saran}

Panel dan soalr cell ini sangat baik digunakan pada sistim irigasi yang sulit untuk membuat waduk dan saluran pembawa.

Disarankan menggunakan komponenkomponen DC untuk melakukan pengontrolan. Karena pada saat melakukan pengoperasian sistim panel dan pompa kita tidak mengunakan Konverter lagi dan berpengaruh pada penghematan energy dan kinerja dari alat tersebut.

\section{DAFTAR PUSTAKA}

Hasan Hasnawiya. 2012. Perancangan Pembangkit Listrik Tenaga Surya di Pulau Saugi. Makasar: Jurnal Riset dan Teknologi Kelautan Volume 10.

http://energiterbarukanonline.blogspot.com/2012/10 /menghitung-kebutuhan-tenaga-surya.html. rabu, 28 agustus 201316.17 WIB.

http://jurnal.untad.ac.id/jurnal/index.php/SMARTE K/article/download/438/375.(24 Oktober 2013. Jam 9.

Pagliaro Mario, Giovanni Palmisano, dkk. 2008. Flexible Solar Cell. Italy: WILEY-VCH.

http://duniatehnikku.wordpress.com/2011/10/05 arti-dan-fungsi mcbmccb.

http://my-smt.blogspot.com/2012/07/cara-kerja relay.html.

http://bocahisonan.blogspot.com/2011/09/selector switch.html.

http:// Cara Kerja Relay - Mengenal Lebih Dekat SMT Yamaha.htm.

http:// DUNIA LISTRIK DAN ELEKTONIKA SELECTOR SWITCH.htm.

http:// /NONO HARYONO Timer_Penghitung waktu.htm.

http:// Prinsip Kerja Relay.htm.

http:// TDR Time Delay Relay _ Timer.htm. 